\title{
A comparison between Chinese finger trap and Roman sandals suture in peritoneal dialysis catheters for chronic kidney disease applied in veterinary medicine
}

DOI: $10.35530 / 1 T .071 .01 .1722$

BOGDAN ALEXANDRU VIȚĂLARU

MĂDĂLIN ION RUSU

\section{ABSTRACT - REZUMAT}

A comparison between Chinese finger trap and Roman sandals suture in peritoneal dialysis catheters for chronic kidney disease applied in veterinary medicine

Catheters designed for chronic peritoneal dialysis have Dacron cuffs meant to protect the patient against bacterial infection and catheter migration that may lead to a high peritonitis rate in case of extensive use. Peritoneal catheter is fixed by suturing the skin with a non-absorbable monofilament thread ranging from 4/0 to 2/0. The two types of sutures most commonly used are Roman sandal and Chinese fingertrap. In this study we selected 44 dogs, both males and females with CKD (Chronic Kidney Disease) undergoing peritoneal dialysis. We have created two groups: first group (A) of 22 patients were treated using a peritoneal catheter for chronic treatment, with Roman sandal suture and the second group of 22 patients $(B)$ were treated using a peritoneal catheter for chronic treatment, with Chinese fingertrap suture. All patients from group A kept the catheters until the end of the treatment (22 out of 22, 100\%). Eight out of 14 patients (36.36\%) from group B needed secondary suture. Four out of the eight patients (18.18\%) form the group $B$ needed secondary suturing because of the suture weakening. Three out of the eight patients (13.63\%) form the group $B$ needed secondary suturing of the catheter because of the skin rupture at the initial placement spot of the suture. One of the eight patients (4.54\%) form the group B needed secondary suturing of the catheter because of the catheter replacement, due to the weakening of the suture and its lack of resistance to the aggression manifested by the patients.

Keywords: peritoneal, dialysis, catheter, suture, polypropylene, veterinary

O compariție între sutura Chinese fingre trap și Roman sandal utilizate la cateterele de dializă peritoneală în terapia bolii renale cronice aplicate în medicina veterinară

Cateterele pentru dializă peritoneală cronică au manșete de Dacron menite să protejeze pacientul împotriva infecțiilor bacteriene și migrării cateterului, care pot duce la o rată ridicată a peritonitei în cazul utilizării prelungite. Cateterul peritoneal este fixat prin sutura pielii cu un fir monofilament neabsorbabil, variind de la 4/0 la 2/0. Cele două tipuri de suturi utilizate cel mai frecvent sunt Roman sandal și Chinese fingertrap. În acest studiu, am selectat 44 de câini, atât masculi, cât și femele, cu BRC (bolală renală cronică) supuși dializei peritoneale. Am creat două grupuri: primul grup (A) din 22 de pacienți a fost tratat utilizând un cateter peritoneal pentru terapia cronică, cu sutură Roman sandal, iar al doilea grup de 22 de pacienți $(B)$ a fost tratați utilizând un cateter peritoneal pentru tratamentul cronic, cu sutura Chinese fingertrap. Toți pacienții din grupul A au păstrat cateterul până la sfârșitul tratamentului (22 din 22, 100\%). Opt din 14 pacienți (36,36\%) din grupul B au nevoie de o sutură secundară. Patru dintre cei opt pacienți $(18,18 \%)$ din grupul B au nevoie de sutură secundară din cauza slăbirii suturii. Trei dintre cei opt pacienți $(13,63 \%)$ din grupul B au avut nevoie de sutură secundară a cateterului din cauza rupturii pielii la locul inițial de plasare a suturii. Unul dintre cei opt pacienți (4,54\%) din grupul B a necesitat sutură secundară a cateterului din cauza înlocuirii cateterului, a slăbirii suturii și a lipsei de rezistență la agresiunea manifestată de către pacient.

Cuvinte-cheie: peritoneală, dializă, cateter, sutură, polipropilenă, veterinară

\section{INTRODUCTION}

Dialysis represents the separation process of a colloidal dispersion substance from molecular dispersion particles, based on the property of certain membranes to retain only colloidal particles [1-2].

Peritoneal dialysis is indicated in various cases of intoxication and metabolic abnormalities. It can also be employed to remove dialyzable toxins, such as ethylene glycol, ethanol, barbiturates, propoxyphene and hydantoin, as well as in cases of electrolyte imbalances, such as hyperkalemia [1, 3].

Dialysis is also indicated in patients showing acute nonanuric uremia, when blood urea nitrogen (BUN) reaches levels over $100 \mathrm{mg} / \mathrm{dl}$ or when creatinine is higher than $10 \mathrm{mg} / \mathrm{dl}$ [4].

Peritoneal dialysis is contraindicated in patients with peritoneal adhesions, fibrosis or abdominal malignant tumors [4].

The ideal catheter for dialysis allows for an adequate administration and evacuation of the dialysate, it determines minimum subcutaneous losses, it minimizes infection both in the peritoneal cavity and in the subcutaneous tissue [1].

Catheters for acute dialysis are placed percutaneously, under local anaesthesia, with the help of a stiletto and they require immediate heparinization. These 
catheters are usually straight with orifices at the distal end. Acute catheters generally do not have Dacron cuffs in order to protect the patient against bacterial infection and catheter migration, that may lead to a high peritonitis rate in case of extensive use [5-8].

Catheters for chronic peritoneal dialysis have specific models, both intraperitoneal and extraperitoneal, in order to reduce secondary effects and to minimize blockage. These catheters are made of silicon, rubber or polyurethane $[2,6]$.

Catheters designed for chronic peritoneal dialysis have Dacron cuffs meant to protect the patient against bacterial infection and catheter migration that may lead to a high peritonitis rate in case of extensive use [1, 9-10].

After the placement, the peritoneal catheter is fixed in place by suturing the skin with a non-absorbable monofilament thread ranging from $4 / 0$ to $2 / 0$. The two types of sutures most commonly used are the Roman sandal and the Chinese fingertrap [1, 11].

The most monofilament thread used in peritoneal dialysis catheter placement is polypropylene (PP). Polypropylene (PP), also known as polypropene, is a thermoplastic polymer used in a wide variety of applications. It is produced via chain-growth polymerization from the monomer propylene. Polypropylene belongs to the group of polyolefins and is partially crystalline and non-polar. Its properties are similar to polyethylene, but it is slightly harder and more heat resistant. It is a white, mechanically rugged material and has a high chemical resistance. Polypropylene is the second-most widely produced commodity plastic (after polyethylene) and it is often used in packaging and labelling.

Once surgically placed, in human medicine, peritoneal dialysis catheters should be used after at least 10 to 14 days. This period of time allows for wound healing, scar formation around the Dacron cuffs and minimization of dialysate leakage around the penetration site of the catheter. For obvious reasons, in veterinary medicine, peritoneal dialysis requires the

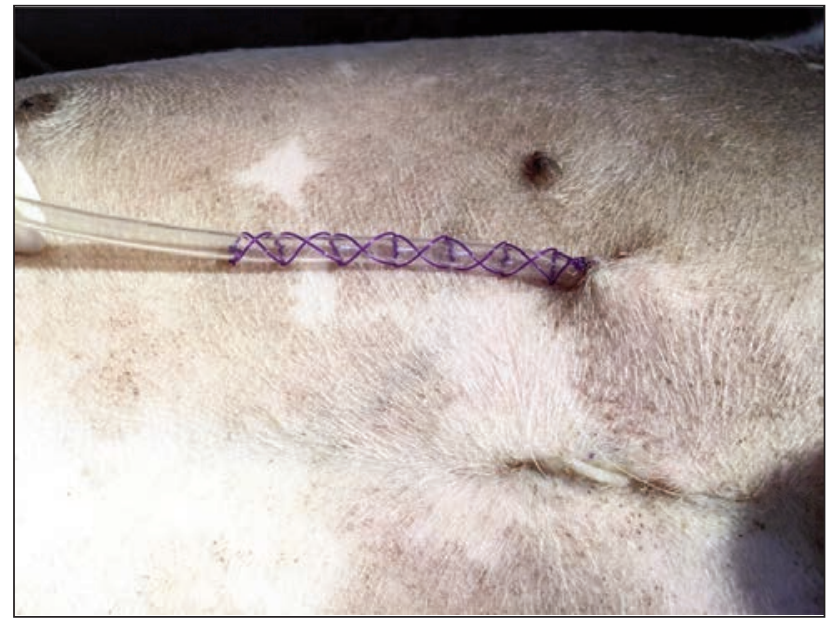

Fig. 1. Roman sandal suture for the temporary peritoneal catheter in dogs with CKD (orig.) immediate use of the peritoneal catheters, since most of the cases are major emergencies and they cannot be postponed for such duration of time [1]. In this study, we have tested peritoneal catheters surgically placed with two types of sutures: Roman sandal and the Chinese fingertrap.

\section{MATERIALS AND METHODS}

In this study we have selected 44 dogs, both males and females with CKD (Chronic Kidney Disease) undergoing peritoneal dialysis. The study started in January 2014 and finished in June 2019. All patients were tested for other associated pathologies and none of the selected patients presented other morbidities of infections of the peritoneal cavity or at the skin, around the catheter placement area.

The patients' age has two to 16 years old and the longest period that they were submitted to peritoneal dialysis has 18 months. The shortest period of treatment was 14 months.

The diseases that were treated were: CKD after acute intoxication with ethylene glycol, babesiosis, or CKD age induced.

We have created two groups of patients: first group (A) of 22 patients were treated using a normal peritoneal catheter for chronic treatment, with two Dacron cuffs and Roman sandal suture and the second group of 22 patients (B) were treated using a normal peritoneal catheter for chronic treatment, with two Dacron cuffs and Chinese fingertrap suture.

In both groups, the peritoneal catheters were placed under general anaesthesia and the catheters were placed using a surgical technique and they required immediate heparinization. The surgical placement of the catheter allowed the visualization of the abdominal cavity and it is useful in omentectomy. Surgical omentectomy was also recommended due to the high risk of catheter blockage by the omentum. Peritoneal dialysis catheters were trimmed (cut), resizing them at the desired level for entering the peritoneal cavity, in order to reach the bottom of the

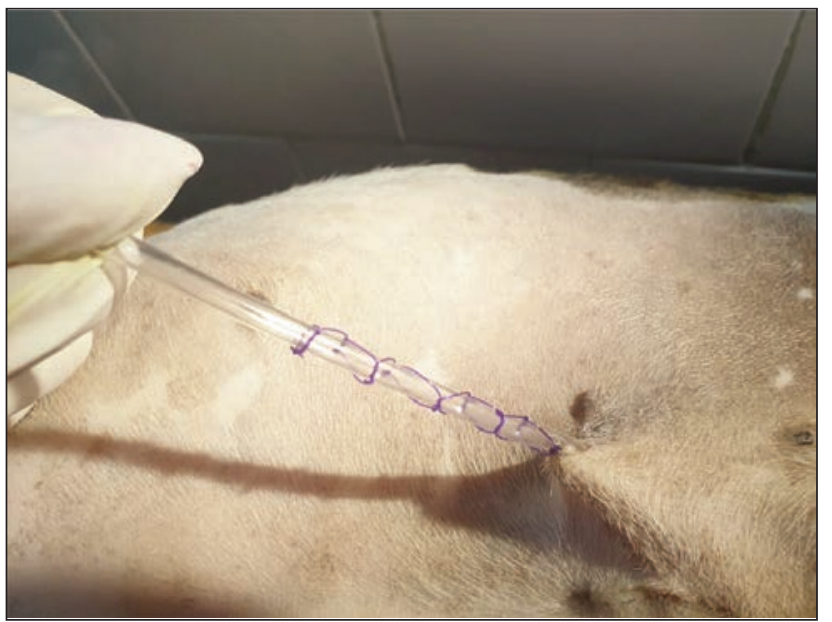

Fig. 2. Chinese fingertrap suture for the permanent peritoneal catheter in dogs with CKD (orig.) 
Douglas pouch. The catheters were pre-measured and, after being cut, they were inserted into the cavity. The abdominal muscles were sutured using an absorbable monofilament thread and the last suture, or a separate suture point, was anchored in the distal Dacron cuff of the peritoneal catheter. Subsequently, the anterior end of the catheter was passed through a subcutaneous lateral tunnel and it was exteriorized through the skin at $3-5 \mathrm{~cm}$ from the main incision line, so that the second Dacron cuff was located at subcutaneous level.

The catheters were fixed in place by suturing the skin with a non-absorbable monofilament thread ranging from $4 / 0$ to $2 / 0$, depending on the patient size.

We used Roman sandal technique in patients from the group $A$ and Chinese fingertrap suture as in patients from the group $B$ in order to place and maintain sutures.

After the placement of the catheters, all patients form group A and group B received special catheter bandaging and dressing of the wound. They also had a special corset to prevent the patient to reach the catheter and to be able to pull it from the peritoneal cavity. All the owners received the same training in catheter handling and patient and wound dressing.

After the initialization of the treatment in the Clinic, all patients were sent home with certain instructions for the owners and submitted to therapy made by the owners, after careful training.

All the patients were treated with the same peritoneal dialysis fluids, form the same medical company. The exchanges and the dwelling time were comparable between the patients.

\section{RESULTS AND DISCUSSIONS}

After analysing all the data form the patient undergoing peritoneal dialysis, we have reached important data. All cases were followed until fully recovered or end of treatment (death). All patients that died were still under peritoneal dialysis.

All patients from the first group, having placed normal peritoneal catheter for chronic treatment, with two Dacron cuffs and Roman sandal suture kept the catheters until the end of the treatment (22 out of 22 , $100 \%)$. Eight out of 14 patients $(36.36 \%)$ from the second group, having placed normal peritoneal catheter for chronic treatment, with two Dacron cuffs and Chinese fingertrap suture, needed secondary suture. Four out of the eight patients (18.18\%) form the group B needed secondary suturing of the catheter because of the suture weakening. Three out of the eight patients $(13.63 \%)$ form the group B needed secondary suturing of the catheter because of the skin rupture at the initial placement spot of the suture. One of the eight patients $(4.54 \%)$ form the group $B$ needed secondary suturing of the catheter because of the catheter replacement, due to the weakening of the suture and its lack of resistance to the aggression manifested by the patients.
The only disadvantage of the technique for placing the permanent dialysis catheters, comparing to the one using the percutaneous placement with local anaesthesia is a longer working duration for the procedure, higher costs, and a longer incision for the catheter placement.

Table 1

\begin{tabular}{|l|c|c|c|c|}
\hline \multicolumn{4}{|c|}{$\begin{array}{c}\text { RESULTS OBTAINED AFTER ANALYSING ALL THE } \\
\text { DATA FROM THE PATIENTS IN THE TWO GROUPS }\end{array}$} \\
\hline \multirow{2}{*}{ Results } & \multicolumn{2}{|c|}{ Group A } & \multicolumn{2}{c|}{ Group B } \\
\cline { 2 - 5 } & Number & $\begin{array}{c}\text { Frequency } \\
(\%)\end{array}$ & Number & $\begin{array}{c}\text { Frequency } \\
(\%)\end{array}$ \\
\hline $\begin{array}{l}\text { Suture } \\
\text { weakening }\end{array}$ & 0 & 0 & 4 & 18.18 \\
\hline Skin rupture & 0 & 0 & 3 & 13.63 \\
\hline $\begin{array}{l}\text { Catheter } \\
\text { replacement }\end{array}$ & 0 & 0 & 1 & 4.54 \\
\hline TOTAL & 0 & 0 & 8 & 36.36 \\
\hline
\end{tabular}

\section{CONCLUSIONS}

Using a permanent dialysis catheter needs longer work duration for the procedure, with higher costs, and a longer incision for the catheter placement, but with less risk.

In our study, all patients from the first group, having placed normal peritoneal catheter for chronic treatment, with two Dacron cuffs and Roman sandal suture kept the catheters until the end of the treatment (22 out of 22, 100\%), which means that Roman sandal suture is a safer and stronger suture, this finding being similar with the research of Thornhill J.A. [9].

Four out of the eight patients $(18.18 \%)$ form the group B needed secondary suturing of the catheter because of the suture weakening, which means that Chinese fingertrap suture is a less safe and stronger suture.

Three out of the eight patients $(13.63 \%)$ form the group B needed secondary suturing of the catheter because of the skin rupture at the initial placement spot of the suture, which means that extra care is needed when suturing the skin at the initial point.

One of the eight patients $(4.54 \%)$ form the group B needed secondary suturing of the catheter because of the catheter replacement, due to the weakening of the suture and its lack of resistance to the aggression manifested by the patients, which also means that Chinese fingertrap suture is a less safe and stronger suture, data being similar with the research of Kushwaha and Singh [10].

\section{ACKNOWLEDGEMENTS}

This project is funded by the Ministry of Research and Innovation through Program I - Development of the National Research and Development System, Subprogram 1.2 - Institutional Performance-Projects for Excellence Financing in RDI, Core Programs: Contract PN 18N/2019. 


\section{REFERENCES}

[1] Vițălaru, A.B, Ștefănescu, A., Peritoneal Dialysis in small animals, Ed. Printech, București, 2018

[2] Stojimirovici, B., Trbojevic-Stankovic, J., Animal models in peritoneal dyalisis, In: Scand. J. La. Anim, Sci., 2007, 34, 4

[3] Stokes, J.E., Bartges, J.W., Causes of acute renal failure, In: Compend. Contin. Educ. Pract. Vet., 2006

[4] Acierno, M.J., Labato, M., Kidney Diseases and Renal Replacement Therapies, An Issue of Veterinary Clinics: Small Animal Practice, Elsevier-Saunders, Ottawa, 2011

[5] Subtirica, A.I., Banciu, C.A., Chivu, A.A.-M., Dinca, L.C., Nanofibres made from biocompatible and biodegradable polymers, with potential application as medical textiles, In: Industria Textila, 2018, 69, 1, 55-58, http://doi.org/10.35530/IT.069.01.1502

[6] McQuiston, J.H., Ehrlichiosis and Related Infections, The Merck Veterinary Manual, 2014

[7] Muhammad, M., Li, N.-W., Muhammad, S.A., Muhammad, K.M., Investigation of various factors affecting the coefficient of friction of yarn by using Taguchi method, In: Industria Textila, 2019, 70, 3, 211-215, http://doi.org/10.35530/IT.070.03.1555

[8] Yanhui, L., Ruitao, J., Mian, W., Shaoju, F., Peihua, Z., Degradation and biocompatibility behaviors of fully covered biodegradable polydioxanone biliary stent for human body, In: Industria Textila, 2019, 70, 5, 393-397, http://doi.org/10.35530/IT.070.05.1344

[9] Thornhill, J.A., Peritonitis associated with peritoneal dialysis: diagnosis and treatment, In: J. Am. Vet. Assoc., 1983, 182,721

[10] Kushwaha, R., Singh, N., Peritoneal dialysis in animals - A review, In: The Internet Journal of Veterinary Medicine, 2008, 7, 1

[11] Thornhill, J.A., Peritoneal dialysis in the dog and cat: an update, In: Compend. Cortin. Educ. Prac. Vet., 1981, 3, 20-34

\section{Authors:}

\section{BOGDAN ALEXANDRU VIȚĂLARU ${ }^{1}$, MĂDĂLIN ION RUSU² ${ }^{2}$, CARMEN MIHAI ${ }^{3}$, ALEXANDRU CHIOTOROIU $^{4}$}

${ }^{1}$ University of Agricultural Sciences and Veterinary Medicine Bucharest, Faculty of Veterinary Medicine Bucharest, Department of Clinical Sciences, Splaiul Independenței, 105, Bucharest, Romania e-mail: alexandrumv@yahoo.com

${ }^{2}$ National Institute of R\&D for Optoelectronics, INOE 2000, 409 Atomistilor Str., Magurele, Jud. IIfov, Romania e-mail: rusu_madalin@yahoo.com

${ }^{3}$ The National Research and Development Institute for Textiles and Leather, IT Research Department in Industrial Engineering, Department, 030508, Bucharest, Romania

${ }^{4}$ General Surgery - Emergency Hospital Bucharest, Romania e-mail: chiotoroiu@yahoo.com

Corresponding author:

BOGDAN ALEXANDRU VIȚĂLARU

e-mail: alexandrumv@yahoo.com

MĂDĂLIN ION RUSU

e-mail: madalin@inoe.ro 